\title{
DEEP SEA FISH RESOURCES DIVERSITY AND POTENTIAL IN THE WATERS OF WESTERN SUMATERA OF THE EASTERN INDIAN OCEAN
}

\author{
Badrudin", Wudianto"), Ngurah N. Wiadnyana"', and Subhat Nurhakim")
}

\begin{abstract}
The availability of data and information on the diversity and potential of fish resources provide important aspects for exploitation and management. Most of the deep sea regions provide the most widely habitat, but until recently information on its biodiversity and potential is very little. Data analyzed were parts of the results of exploratory trawling using the RN Baruna Jaya IV carried out in June to July 2005. The most importance species in term of numbers were the lantern fish, Diaphus sp.1, the rat tails macrourid, Caelorinchus divergens, the neoscopelids, Neoscopelus macrolepidotus, the spinyfins, Diretmoides pauciradiatus, the alepocephalid, Bajacalifornia erimorensis, and the trachichthyds Hoplostetus crassispinus. Analysis of fish resources indicated that the lowest density of about 0.08 tonnes $\mathrm{km}^{-2}$ was observed in the depth zone of 751 to $1,000 \mathrm{~m}$ in the waters of the north western part of Simeuleu and the highest density of 17.7 tonnes $\mathrm{km}^{-2}$ was occurred in the depth zone 500 to $750 \mathrm{~m}$ in the waters of the western part off Banda Aceh. In relation with the environmental aspects such as the huge pressure and scarcity of food supply, it is likely that the deep sea fishes might have a very high sustainment for survive. The most interesting aspect is that the chemical substances of their flesh, such as proteins, lipids and others will need further pharmacological analysis and research. It is advised that exploitation of deep sea fish resources nowadays shoud be directed to get the benefit from the resources diversity and bioactive substances rather than catching fish for consumption.
\end{abstract}

KEYWORDS: deep sea fish, diversity index, catch rate, catch composition, stock density, Western Sumatera, Eastern Indian Ocean

\section{INTRODUCTION}

The demersal resources are a group of fishes that most of their life cycle living at or around the bottom waters. Characteristics of demersal fish behaviour compared with those pelagics fish are forming a relatively smaller school, lower movement, and relatively shorter migration ranges. Catch compositions of the most economically important demersal fish in the continental shelf area and relatively shallow waters are usually consisted of red snappers, silver bellies, white pomfrets, groupers, croackers, and catfish (Saeger et al., 1976). The fishing gears used for the demersal fish exploitation are trawl, bottom long line, bottom gill net, traps and hook and line. The shallow waters demersal fish has been widely known and easily found in most landing places and fish market, however, most of the deepsea demersal fish are rarely encountered while some fishes provide as identified new species that have not even been found in the literatures. As demersal fish had a relatively short distance migration range, their fishing grounds in the Indian Ocean untill recently are still limited to the narrow continental shelf areas. Based on the available marine charts, the fishing areas are considered not more than $100 \mathrm{~m}$ isodepth. In relation with the relatively limited capability in both fishing gears and fishing fleets of most Indonesian fishers, it is believed that the deepsea demersal fish resources at the depth range more that $100 \mathrm{~m}$ are considered untapped. The fish resources include deep sea shark and rays, groupers, snappers (Etelis sp.) and some conger eels (Wibowo, 2005). Some deep sea fish that have been found during the exploratory bottom long lining in the Sunda Strait were Gepyroberix sp., and Peristedion sp. (Hufiadi et al., 2003). The first fish species can be considered as food fish, while the later has been known as a very poisonous fish.

In relation with the fish resources potential, information on this aspect regarding the deep-sea fish resources in Indonesian waters is still very scare compared to the similar aspect on the shallow demersal fishes that have been widely reported (Losse \& Dwiponggo, 1977; Dwiponggo \& Badrudin, 1978; 1979; 1980; Badrudin \& Sumiono, 2002; Badrudin et al., 2002; 2004; 2004a; 2005).

Most of the deep sea region provides the most widely habitat with little information on its biodiversity. Ninety percent of the ocean volume consisted of deep water which are dark, cold. Mean while information on the aspect's of life is still very rare (Nybakken, 1986). The main environmental factors affecting deep-sea region are light, hydrostatics pressure, salinity, temperature, oxigen, and food supply. These factors will undoubtedly

\footnotetext{
". Research Institute for Marine Fisheries, Muara Baru-Jakarta

*) Research Center for Capture Fisheries
} 
affect the behaviour, life, survival, sustainment and diversity of most organisms including fish.

This paper provides information that can be used as a benchmark for further research and assessment activities in both similar marine waters or other marine areas with similar waters characteristics and biophysical conditions. Results of the anaylisis presented in this paper provide a complementary information found in the results of the exploratory trawling carried out by the RN Baruna Jaya IV (Anonymous, 2006).

\section{MATERIALS AND METHODS}

Data analyzed were parts of the results of exploratory trawling using the R/V Baruna Jaya IV, carried out in the framework of The JapanIndonesia Deep Sea Fisheries Resources Joint Exploration Marine Research 2004, with one of the main objectives is to study the catch per unit area as an index of abundance of the deepsea demersal fish resources in the Indian Ocean Southern Java and Western Sumatera (Anonymous, 2006).
A total of 50 trawl fishing stations was done completly during June to July 2005 . The catches of each species or species group were weighted, counted, and recorded in the fishing log sheet. The combined data for analysis were inputted in the form of Excel format. Trawl sampling sites include the waters of SE Enggano (S-1 area), Western off Bangkulu (S-2 area), NW of Simeuleu (S-4 area), and Western off Banda Aceh (S-5 area). Due to some technical problems (Anonymous, 2006), trawling activity in the S-3 area has been cancelled (Figure 1). Exploratory fishing covered the depth range of 250 to $1,200 \mathrm{~m}$, while data analysis was limited only to the exploratory results carried out in the western Sumatera of the Indian Ocean. These data were grouped into three depth fishing zones, the $<500 \mathrm{~m}, 500$ to $750 \mathrm{~m}$, and 751 to $1,000 \mathrm{~m}$. Estimation of stock density and standing stock size was carried out by using the swept area method following Saeger et al. (1976) with the assumption that the constant mouth openning of the trawl was $50 \%$ of the head rope length and escapement factor was $75 \%$. Species identifications were done following Nakabo (2002).

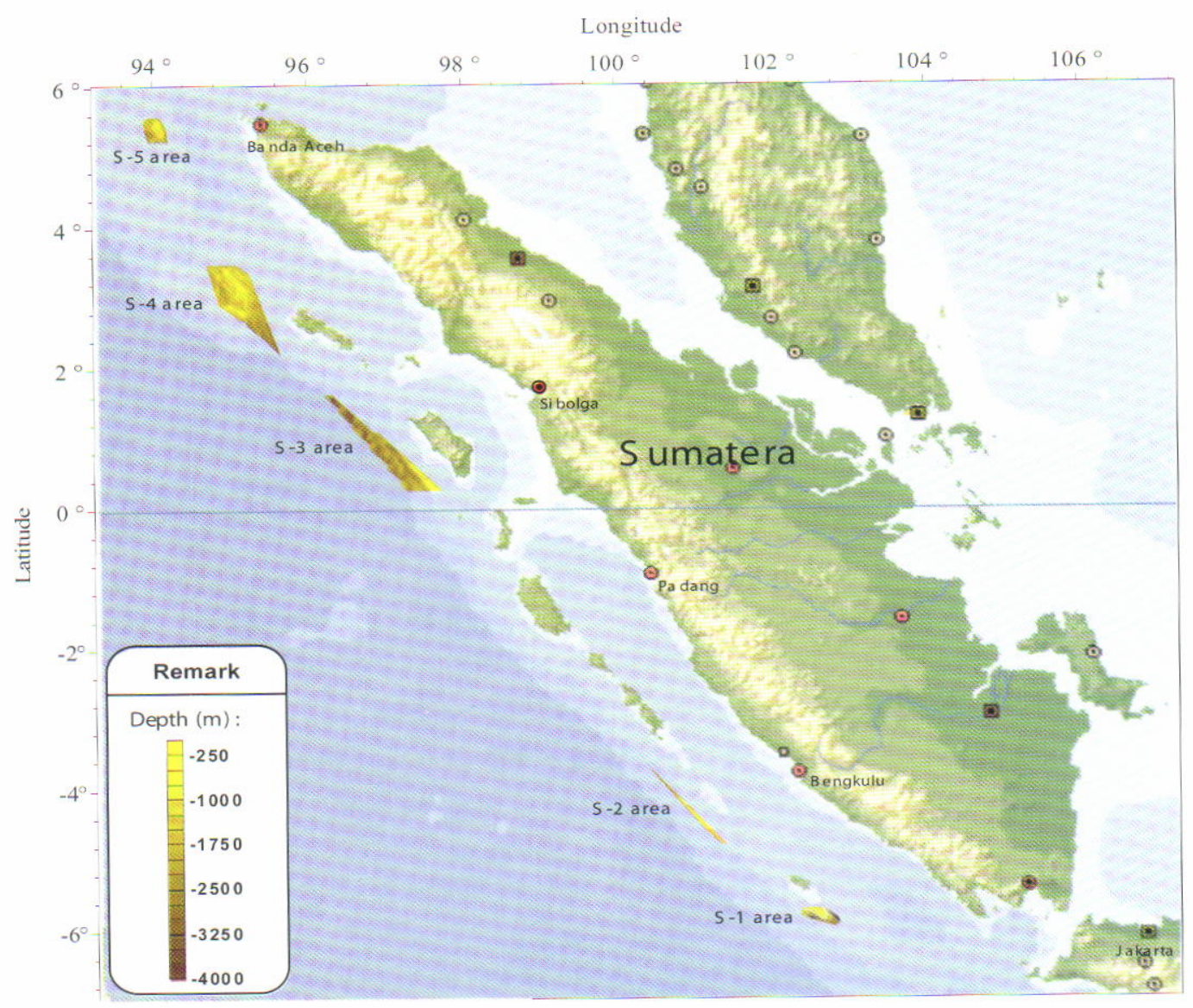

Figure 1. Deep sea trawl sampling sites (S-1 = SE Enggano; S-2 = W-off Bengkulu; $S-3=W$ of Nias, where trawling site has been cancelled; and S-4= NW Simeuleu; S- $5=$ W off Banda Aceh). 
Calculations of diversity indices were limited to:

1. Richness Index of Margaleff:

$R_{1}=(S-1) / \ln (n)$

where:

$S=$ number of species

$\mathrm{N}=$ total number of individual fish of all species

2. Diversity Index of Shannon:

$H=\sum\left[\left(n_{i} / n\right) \ln \left(n_{i} / n\right)\right]$

where:

$n=$ total number of individual fish of all
species
$n_{i}=$ number of $i^{\text {th }}$ species

3. Diversity Index of Simpson:

$\lambda=\sum\left[\left(n_{i}\left(n_{i}-1\right) /(n(n-1)\right.\right.$

following the procedure explained in Ludwig \& Reynold, (1988).

\section{RESULTS AND DISCUSSION}

\section{Total Catch}

A wide range of marine organisms was found in the catch. These included fishes group of both bony fish and elasmobranch. Other groups were crustaceans, cephalopods, echinoids, asteroids, ophiuroids, holoturoids, and anthozoa. A total of more than 550 species was found in the catch, of which until now some species were still unknown and not yet found in the literatures. The following analysis will only be limited to the fish resources.

\section{Diversity}

Biological diversity or biodiversity is the diversity of living things. The greater the variety of animal, the greater the biodiversity. The number of species and the number of individuals of each species are used to estimate biodiversity index. Biodiversity can vary with location, habitat, season, and other factors as well as with the means of estimation.

\section{The Waters of the SE Part of Enggano}

It is likely that within the depth range of 250 to $1,000 \mathrm{~m}$ in this waters, the number of species seems to increase toward the deeper waters. This is reflected in the Richness index, where the index in the depth zone 750 to $1,000 \mathrm{~m}$ is $40.0 \%$ higher than the index in the depth zone 500 to $750 \mathrm{~m}$. Similary the index in the later depth zone was $40.5 \%$ higher than the index in depth zone $<500 \mathrm{~m}$.

This phenomenon is also happened to the Shannon index, where the values seems to decrease toward the deeper waters. In other words, the greater the depth zone the smaller the diversity. The highest index, $H=2,171$, occurred in the depth zone of $<500 \mathrm{~m}$, while in the respective deeper zones these value were 37.5 and $11.4 \%$ decreased (Table 1). The value of Simpson index reflects the domination of certain species. This index is also known as the index of domination. It seems that within the waters of Enggano, the species domination occurred in the deeper waters. The three fish groups abundantly found in the depth zone of 750 to $1,000 \mathrm{~m}$, were the macrourids, the melanonids and the ophidiids. From a total of 759 fish caught, their percentage was around $50 \%$. The most abundant macrourid species was Caelorinchus divergens reaching to about $12.5 \%$, while the other members of family Macrouridae with the total percentage of almost $19 \%$ consisted of

Table 1. Richness index $\left(R_{1}\right)$, Shannon index $(H)$, and Simpson index $(\lambda)$ of deep sea fish resources in the waters of Western Sumatera, Eastern Indian Ocean

\begin{tabular}{|c|c|c|c|c|}
\hline Area & Index/Depth' & $<500 \mathrm{~m}$ & $500-750 \mathrm{~m}$ & $750-1,000 \mathrm{~m}$ \\
\hline Enggano & $\begin{array}{l}\mathrm{R}_{1} \\
\mathrm{H}\end{array}$ & $\begin{array}{c}6.47 \\
2.171\end{array}$ & $\begin{array}{l}9.09(+40.5 \%) \\
1,357(-37.5 \%)\end{array}$ & $\begin{array}{c}12.82(+40 \%) \\
1,203(-11.4 \%)\end{array}$ \\
\hline Bengkulu & $\begin{array}{l}\lambda \\
R_{1} \\
H\end{array}$ & $\begin{array}{c}0.233 \\
- \\
-\end{array}$ & $\begin{array}{c}0.317(+36.1 \%) \\
8.36 \\
0.344\end{array}$ & $\begin{array}{l}0.049(-84.5 \%) \\
10.00(+19.6 \%) \\
0.498(+44.8 \%)\end{array}$ \\
\hline Simeuleu & $\begin{array}{l}\lambda \\
\mathrm{R}_{1} \\
\mathrm{H}\end{array}$ & $\begin{array}{l}- \\
3.036 \\
0.401\end{array}$ & $\begin{array}{c}0.043 \\
15,061(+396.1 \%) \\
2,394(+497.0 \%)\end{array}$ & $\begin{array}{l}0.067(+55.8 \%) \\
15,403(+2.3 \%) \\
1,956(-18.3 \%)\end{array}$ \\
\hline \multirow[t]{2}{*}{ Banda Aceh } & $\begin{array}{l}\lambda \\
R_{1} \\
H\end{array}$ & $\begin{array}{l}0.489 \\
4.397 \\
0.609\end{array}$ & $\begin{array}{c}0.089(-81.8 \%) \\
7,338(+66.9 \%) \\
1,812(+198.0 \%)\end{array}$ & $\begin{array}{l}0.044(-50.6 \%) \\
9,232(+25.8 \%) \\
1,019(-43.8 \%)\end{array}$ \\
\hline & $\lambda$ & 0.839 & $0.281(-66.5 \%)$ & $0.255(-9.3 \%)$ \\
\hline
\end{tabular}


Caelorinchus sp.1, Gadamus colletti, Ventrifossa sp.1, Nezumia sp.2, Nezumia sp.1, and Pseudonezumia japonica (Table 2).

\section{The Waters of the Western Part off Bengkulu}

Due to the limited area of the trawlable ground, number of trawl haul allocated in this waters was only two hauls in the 500 to $750 \mathrm{~m}$ depth zone and another two hauls in the 750 to $1,000 \mathrm{~m}$ depth zone. As in the Enggano area, the diversity indices including Richness, Shannon as well as Simpson index seem to increase toward the deeper waters. Richness index in the 750 to $1,000 \mathrm{~m}$ depth zone was about $19.6(20 \%)$ higher than in the 500 to 750 $m$ depth zone. Similarly, the Shannon index in the depth zone 750 to $1,000 \mathrm{~m}$ was $45 \%$ higher, while the Simpson index was $56 \%$ higher than in the depth zone 500 to $750 \mathrm{~m}$ (Table 1). The most abundance species in each of the two depth zone in the western part off Bengkulu as represented by the highest percentage was placed by the macrourid Caelorinchus divergens. This benthopelagic species seems to have either a wider range of depth distribution or the bottom habitat in this area are similar. The percentage of this species in the two depth zones was $11 \%$ and $19 \%$ respectively (Table 2 ).

\section{The Waters of the NW Part off Simeuleu}

Species diversity in the $<500$ m depth zone was rather poor compared with diversity in the deeper zone. As reflected by the Richness index which is only 3.0 , the Richness index in the deeper waters of 15,061 was more than five times higher, an increase of about $396 \%$. Similar phenomenon with the value of Shannon index, where in the $<500 \mathrm{~m}$ depth zone thie value of $\mathrm{H}=0.4$, in the 500 to $750 \mathrm{~m}$ depth zone was six times higher as there was an increase to about $496 \%$ (almost $500 \%$ ), while in the 750 to $1,000 \mathrm{~m}$ depth zone was five times higher (Table 1) compared with the $<500 \mathrm{~m}$ depth zone.

The occurring Simpson diversity index is likely consistence with the Richness index, where the higher the value of the index the lower the diversity. The lower value of the Simpson index occurred in the 750 to $1,000 \mathrm{~m}$ depth zone, mean higher diversity occurred as indicated by the higher Richness index. The lowest value of Simpson index occurred in the 750 to 100 depth zone mean that

Table 2. The dominant families and species of the deep sea fish in the Western Sumatera (\% of $N$ )

\begin{tabular}{|c|c|c|c|c|c|}
\hline Depth ranges (m) & $<500$ & $500-750$ & & $750-1,000$ & \\
\hline SE Enggano & & & & & \\
\hline Myctophidae & & Neoscopelidae & & Macrouridae & \\
\hline Diaphus sp. 1 & 43.9 & $\begin{array}{l}\text { Neoscopelus } \\
\text { macrolepidotus }\end{array}$ & 53.1 & $\begin{array}{l}\text { Caelorinchus } \\
\text { divergens }\end{array}$ & 12.5 \\
\hline Ostracoberycidae & & Caproidae & & Caelorinchus sp. 1 & 5.5 \\
\hline $\begin{array}{l}\text { Ostracoberyx } \\
\text { dorgenys }\end{array}$ & 16.8 & Antigonia sp. & 17.5 & Gadamus colletti & 3.4 \\
\hline Acropomatidae & & Myctophidae & & Ventrifossa sp. 1 & 3.0 \\
\hline Synagrops japonicus & 5.6 & Diaphus sp. 1 & 3.3 & Nezumia sp. 2 & 2.6 \\
\hline Grammicolepididae & & Moridae & & Nezumia sp. 1 & 2.2 \\
\hline $\begin{array}{l}\text { Xenolepidichthys } \\
\text { dalgleishi }\end{array}$ & 5.4 & Halargyreus sp. & 2.6 & $\begin{array}{l}\text { Pseudonezumia } \\
\text { japonica }\end{array}$ & 2.0 \\
\hline Total catch $(\mathbf{N})$ & 3,103 & & 1,586 & & 759 \\
\hline Western off Bengkulu & & Macrouridae & & Macrouridae & \\
\hline & & Caelorinchus divergens & 11.1 & $\begin{array}{l}\text { Caelorinchus } \\
\text { divergens }\end{array}$ & 19.3 \\
\hline & & Gadamus colletti & 5.8 & $\begin{array}{l}\text { Gadamus colletti } \\
\text { Nezumia sp. } 1\end{array}$ & 1.5 \\
\hline & & Scopelengys tristis & 9.9 & Alepocephalidae & \\
\hline & & $\begin{array}{l}\text { Neoscopelus } \\
\text { macrolepidotus }\end{array}$ & 7.0 & Rouleina guentheri & 11.9 \\
\hline & & Sternoptychidae & & $\begin{array}{l}\text { Bajacalifornia } \\
\text { erimoensis }\end{array}$ & 6.3 \\
\hline & & Sternoptyx sp. & 4.7 & Alepocephalidae sp. 1 & 4.1 \\
\hline & & $\begin{array}{l}\text { Alepocephalidae } \\
\text { Rouleina guentheri }\end{array}$ & 4.7 & $\begin{array}{l}\text { Talismania sp. } \\
\text { Ipnopidae }\end{array}$ & 1.5 \\
\hline & & Bajacalifornia erimoensis & 4.1 & Bathypterois atricolor & 5.2 \\
\hline Total catch (N) & & & 171 & & 270 \\
\hline
\end{tabular}


Table 2. Countinous

\begin{tabular}{|c|c|c|c|c|c|}
\hline \multirow{6}{*}{\begin{tabular}{l}
\multicolumn{1}{c}{ Depth ranges $(\mathrm{m})$} \\
NW part of Simeuleu \\
Ostracoberycidae \\
Ostracoberyx \\
dorgenys \\
Grammicolepididae \\
Xenolepidichthys \\
dalgleishi \\
Triacanthodidae
\end{tabular}} & \multirow[t]{2}{*}{$<500$} & \multicolumn{2}{|l|}{$500-750$} & \multicolumn{2}{|l|}{$750-1,000$} \\
\hline & & Diretmidae & & Ophidiidae & \\
\hline & 68.4 & Diretmoides pauciradiatus & 21.9 & Lamprogrammus niger & $\begin{array}{c}11 . \\
4\end{array}$ \\
\hline & & Macrouridae & & Glyptophidium sp. & 6.2 \\
\hline & 10.4 & Caelorinchus divergens & 10.4 & Ophidiidae sp.1 & 2.3 \\
\hline & & Berycidae & & Macrouridae & \\
\hline Tydemania navigatoris & 8.5 & Beryx splendens & 9.6 & $\begin{array}{l}\text { Caelorinchus } \\
\text { divergens }\end{array}$ & 10.4 \\
\hline $\begin{array}{l}\text { Berycidae } \\
\text { Beryx splendens }\end{array}$ & 6.9 & $\begin{array}{l}\text { Ophidiidae } \\
\text { Glyptophidium sp. } \\
\text { Trachichthyidae } \\
\text { Hoplostethus crassispinus }\end{array}$ & $\begin{array}{l}9.5 \\
8.9 \\
\end{array}$ & $\begin{array}{l}\text { Melanonidae } \\
\text { Melanonus zugmayeri }\end{array}$ & 6.5 \\
\hline Total catch $(\mathbf{N})$ & 376 & & 2,071 & & 1,348 \\
\hline $\begin{array}{l}\text { Western off Banda Aceh } \\
\text { Myctophidae }\end{array}$ & & Ostracoberycidae & & Diretmidae & \\
\hline Diaphus sp.1 & 91.5 & Ostracoberyx dorgenys & 43.1 & $\begin{array}{l}\text { Diretmoides } \\
\text { pauciradiatus }\end{array}$ & 47.2 \\
\hline $\begin{array}{l}\text { Phosichthyidae } \\
\text { Polymytme elongatus } \\
\text { Chloropthalmidae }\end{array}$ & 2.0 & $\begin{array}{l}\text { Diretmidae } \\
\text { Diretmoides pauciradiatus } \\
\text { Trachichthyidae }\end{array}$ & 26.9 & $\begin{array}{l}\text { Nettastomatidae } \\
\text { Nettastoma solitarium } \\
\text { Macrouridae }\end{array}$ & 13.6 \\
\hline Chlorophthalmus sp. 1 & 1.5 & $\begin{array}{l}\text { Hoplostethus } \\
\text { rubellopterus } \\
\text { Nettastomatidae } \\
\text { Nettastoma solitarium } \\
\text { Paralepididae } \\
\text { Notoleptis rissoi }\end{array}$ & $\begin{array}{l}14.4 \\
3.9 \\
2.8 \\
\end{array}$ & $\begin{array}{l}\text { Caelorinchus } \\
\text { divergens }\end{array}$ & 9.3 \\
\hline Total catch $(\mathrm{N})$ & 2,281 & & 3,558 & & 920 \\
\hline
\end{tabular}

diversity in this waters was relatively low but the domination index was high, which mean that the fish community was dominated by a small number of species. The most abundance species in the $<500 \mathrm{~m}$ depth zone was only three species, while in the 500 to $750 \mathrm{~m}$ depth zone was 12 species and in the deeper zone was 14 species. This information indicates that the deep sea fish community in the $<500 \mathrm{~m}$ depth zone was dominated by only three species. As already mention earlier that the very abundance species in the $<500 \mathrm{~m}$ depth zone was only one. This species was Ostracoberyx dorgenys of the family Ostracoberycidae with the percentage number reaching to about $68 \%$ (Table 2). Comparing with the Enggano, area, this species provides the second most abundance in the same depth zone, while in the other deeper zone of both Enggano and off Bengkulu area it was hardly ever found. It is likely that the depth distribution of this species might be relatively limited up to the depth of less than $750 \mathrm{~m}$.

In the 500 to $750 \mathrm{~m}$ and 750 to $1,000 \mathrm{~m}$ depth zone the percentage of the most abundance species was not as high as the percentage in the
$<500 \mathrm{~m}$ depth zone. This appearence indicated that the habitat of fish community in the deeper zone was slightly different compared with the shallower depth zone.

The five most abundance species found in the 500 to $750 \mathrm{~m}$ depth zone were the spinyfins, Diretmoides pauciradiatus (Diretmidae), the macrourid, Caelorinchus divergens, the alfonsinos, Beryx splendens, the ophidiid, Glyptophidium sp., and the slimeheads, Hoplostethus crassispinus of the family Trachichthyidae. The respective percentage compositions of these species were almost $22 \%$, each of the following three species of about $10 \%$ and the last species of almost $9 \%$. The four most abundance species in the 750 to $1,000 \mathrm{~m}$ depth zone were the ophidiid, Lamprogrammus niger, the macrourid, Caelorinchus divergens, the melanonid or pelagic cod, Melanonus zugmayeri and the other ophidiid, Glyptophidium sp., with a lower percentage of about 11,10 , almost 7 , and $6 \%$ respectively (Table 2 ).

The other species found in these two deeper depth zone with different percentage ranging from 
about 4 to $0.5 \%$ were the slimeheads, Hoplostethus crassispinus, similar with the orange roughy, $H$. atlanticus in the southern Australia (Anonymous, 1992), the ipnopids, Bathypterois atricolor, the spinyfins, Diretmoides pauciradiatus, two species of the alepocephalids, Bajacalifornia erimoensis and Rouleina guentheri, the viperfishes, Chauliodus sloani, the neoscopelids, Neoscopelus macrolepidotus, and two species of the myctophids, Lampadena spp.

\section{The Waters of the Western Part off Banda Aceh}

As already mentioned earlier that the Richness index always increased toward the deeper waters in each of the preceding areas, the similar appearences were also happened to the deep sea fish community in northest part of the waters of western Sumatera. Difference with the pattern of Shannon index in the Enggano area where the highest index occurred in the $<500 \mathrm{~m}$ depth zone, and was decreasing toward the deeper zone, the highest index of $\mathrm{H}=1.8$ in the Western part off Banda Aceh occurred in the 500 to 750 depth zone (Table 1). While the pattern of the Richness index in this area which increased toward the deeper waters. This is in line with the occurring reversed pattern of Simpson index that seems to be a normal phenomenon in ecology.

The most abundance species in each of the three depth zone was one species, three species, and two species respectively. The most abundance species in the $<500 \mathrm{~m}$ depth zone in this waters was occupied by the mycthopid, Diaphus sp.1, where approximately $92 \%$ of the total number of individual fish in this depth zone was contributed by this species alone. The two abundance species were placed by the phosichtyds, Polymytme elongatus, followed by the green eyes, Chlorophthalmus sp.1 (Chloropthalmidae).

The first of the most abundance species in the 500 to $750 \mathrm{~m}$ depth zone was placed by Ostracoberyx dorgenys, followed by the spinyfins, Diretmoides pauciradiatus, and the slimeheads, Hoplostethus rubellopterus (Tabel 2). The four abundance species in this zone were Nettastoma solitarium (Nettastomatidae), Notoleptis rissoi (Paralepididae), Caelorinchus divergens (Macrouridae), and the deep sea hairtail, Benthodesmus tenuis (Trichiuridae).

As in the Simeuleu area, where the spinyfins, Diretmoides pauciradiatus provided the most abundance species in the 500 to $750 \mathrm{~m}$ depth zone, in the western part off Banda Aceh area this species respresented the most abundance species in the deeper zone of 750 to $1000 \mathrm{~m}$. Based on this appearence, it is likely that the spinyfins would provide the major inhabitant of the deeper waters of the Eastern Indian Ocean.

\section{Ranking of Importance}

This rank of importance was tabulated based on the abundance data in term of frequency of occurence of the species in each depth zone in the four areas and the percentage to the total number on fish caught. The six species that were frequent to occurr in the catch were tabulated. The high rank of importance was iased on the number of fish caught in each depth zone of the four areas. The myctophids, Diaphus sp.1, represented the first rank of important in the $<500 \mathrm{~m}$ depth zone in the area of both SE Enggano and Western off Banda Aceh. This species was almost absence in the area close to the imaginary equator line, except in the area around Simeuleu at the 500 to $750 \mathrm{~m}$ depth zone with almost close to the lowest rank of important. The rat tails macrourid, Caelorinchus divergens, seems to be represented the main important fish within the depth zone of more than $500 \mathrm{~m}$. It seems that this species provides a relatively cosmopolitant fish as the fish often presented in the catch in each of the four areas. The neoscopelids, Neoscopelus macrolepidotus was likely forming a southern waters inhabitant, as no record of the catches in the northern area of S-5, while in the S-4 area the importance was the lowest rank of the 750 to 1,000 $\mathrm{m}$ depth zone and in the 500 to 750 was close to the lowest rank. The spinyfins, Diretmoides pauciradiatus represented the deeper waters fish similar with the macrourid, Caelorinchus divergens. It is likely that this species prefers to inhabit in the waters of the northern part of the equator. The alepocephalid, Bajacalifornia erimorensis might prefer to inhabit in the deepest depth zone of 750 to $1,000 \mathrm{~m}$, and in the shallower zone of the northern and southern waters close to the equator, while the slimeheads, Hoplostetus crassispinus might represent the northern inhabitant of the western Sumatera waters.

\section{Catch Rates}

Catch rate which is equivalent with the catch per unit of effort provides one of the indices of abundance of fish resources. Fluctuation of catch rates can be assummed as the response of the fish communities against some influencing factors both internal and external. In the exploited fisheries, especially in the shallow coastal waters, fishing pressure provides the most influencing factor. However, what is the most influencing factor affecting the fluctuation of fish abundance in the deep-sea is not known. The availability of data and informations on the catch rates in a certain waters in both spatial and temporal provide one of the 
Table 3. Ranking of importance of the six abundance species in the waters of Western Sumatera, Eastern Indian Ocean

\begin{tabular}{|c|c|c|c|c|c|c|}
\hline $\begin{array}{c}\text { Area } \\
\text { code, } \\
\text { depth } \\
\text { zones } \\
(\mathrm{m})\end{array}$ & $\begin{array}{l}\text { Myctophidae } \\
\text { Diaphus sp. }\end{array}$ & $\begin{array}{c}\text { Macrouridae } \\
\text { Caelorinchus } \\
\text { Divergens }\end{array}$ & $\begin{array}{l}\text { Neoscopelidae } \\
\text { Neoscopelus } \\
\text { macrolepidotus }\end{array}$ & $\begin{array}{c}\text { Diretmoidae } \\
\text { Diretmoides } \\
\text { pauciradiatus }\end{array}$ & $\begin{array}{c}\text { Alepocephalidae } \\
\text { Bajacalifornia } \\
\text { erimorensis }\end{array}$ & $\begin{array}{c}\text { Trachichthydae } \\
\text { Hoplostetus } \\
\text { crasipinus }\end{array}$ \\
\hline S-1 & & & & & & \\
\hline $\begin{array}{l}<500 \\
500-750\end{array}$ & $\begin{array}{l}1 \\
3\end{array}$ & 8 & $\overline{1}$ & ; & - & - \\
\hline $\begin{array}{c}500-750 \\
750-1,000\end{array}$ & $\begin{array}{l}3 \\
-\end{array}$ & 1 & 7 & $\begin{array}{l}1 \\
7\end{array}$ & $\overline{6}$ & - \\
\hline S-2 & & 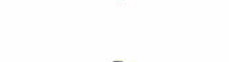 & - & - & - & \\
\hline$<500$ & - & $i$ & $\overline{3}$ & - & $\overline{8}$ & - \\
\hline $\begin{array}{c}500-750 \\
750-1.000\end{array}$ & - & 1 & 7 & - & 3 & - \\
\hline $\begin{array}{c}750-1,000 \\
5-4\end{array}$ & & - & - & - & - & - \\
\hline$<500$ & $\therefore$ & $\overline{2}$ & $\overline{14}$ & 1 & 15 & 5 \\
\hline $\begin{array}{c}500-750 \\
750-1,000\end{array}$ & $\begin{array}{l}17 \\
-\end{array}$ & $\begin{array}{l}2 \\
2\end{array}$ & $\begin{array}{l}14 \\
19\end{array}$ & 7 & 5 & 8 \\
\hline $\begin{array}{c}750-1,000 \\
S-5\end{array}$ & & & - & - & _- & - \\
\hline$<500$ & 1 & $\overline{6}$ & - & 2 & - & 3 \\
\hline $500-750$ & $\overline{6}$ & $\begin{array}{l}6 \\
3\end{array}$ & - & 1 & 7 & 4 \\
\hline
\end{tabular}

most important aspects needed for fish resources exploitation and fisheries development.

In the waters of south eastern part of Enggano both the minimum of $5.5 \mathrm{~kg}$ per $\mathrm{hr}$ and the maximum of $330.1 \mathrm{~kg}$ per $\mathrm{hr}$ were obtained from the depth zone of 500 to $750 \mathrm{~m}$. The average catch rate of the following three depth zone of $<500 \mathrm{~m}, 500$ to $750 \mathrm{~m}$, and 751 to $1,000 \mathrm{~m}$ were $81.0,121.7$, and $103.2 \mathrm{~kg}$ per $\mathrm{hr}$, respectively (Table 4). Catch rate data in the waters of western part off Bengkulu area were based on only two trawl hauls from the depth zone 500 to $750 \mathrm{~m}$ and two trawl hauls in the depth zone 751 to $1,000 \mathrm{~m}$. The respective minimum catch rates were 7.5 and $17.5 \mathrm{~kg}$ per $\mathrm{hr}$, while the maximum were 18.1 and $20.5 \mathrm{~kg}$ per $\mathrm{hr}$, with the average of 12.8 and $19.0 \mathrm{~kg}$ per $\mathrm{hr}$.

Fifty percent of the total number trawl hauls in the Western Sumatera of the eastern Indian Ocean during this cruise were carried out in the waters of North Western Simeuleu. The minimum catch rate of only $3.3 \mathrm{~kg}$ per hr occurred in the depth zone 751 to $1,000 \mathrm{~m}$, while the maximum catch rate of 90.1 $\mathrm{kg}$ per $\mathrm{hr}$ was observed in the depth zone 500 to $750 \mathrm{~m}$. During this cruise, the minimum catch rate in this area provided the lowest catch rate of the whole depth zone in the four areas of western Sumatera. The average catch rates from the three depth zone were $43.4,45.7$, and $25.8 \mathrm{~kg}$ per $\mathrm{hr}$ repectively (Table 4 ).

In the western part off Banda Aceh, the lowest catch rates were found in the the depth zone $<500$ $\mathrm{m}$, while the highest catch rates occurred in the 500 to $750 \mathrm{~m}$ depth zone. The respective average catch rates in the western off Banda Aceh were 8.4, 110.0 , and $84.8 \mathrm{~kg}$ per hr (Tabel 4). Based on these catch rates data, through some further calculations procedures and asumptions, a number of stock parameters such as stock density (Shindo, 1973), standing stock size (Saeger et al., 1976) as well as potential yield (Gulland, 1983) of the deep sea fish resources in the western part of Sumatera may be estimated.

\section{Stock Density and Standing Stock Size}

In the waters of the South Eastern part of Enggano the estimated density of fish varied from the minimum of 0.6 to 0.8 tonnes $\mathrm{km}^{-2}$ to the maximum of 3.3 to 9.9 tonnes $\mathrm{km}^{-2}$, with the average of 2.3 to 3.8 tonnes $\mathrm{km}^{-2}$. Based on these figures, the estimated standing stock sizè (biomass) in this waters was about 3,176 tonnes, derived from the following depth zone of $<500 \mathrm{~m}$, 500 to $750 \mathrm{~m}$, and 751 to $1,000 \mathrm{~m}$ of about 700 ; 1,179; and 1297 tonnes, respectively (Table 5).

Due to the limited number of trawl hauls in the western part off Bengkulu waters which was only covered two depth zone of 500 to $750 \mathrm{~m}$ and 751 to $1,000 \mathrm{~m}$, the estimated mean density of fish was between 0.4 to 0.6 tonnes, with the total biomass of about 62.5 tonnes, which was originated from the two depth zone of about 7.5 and 55 tonnes respectively. Based on 25 trawl fishing stations carried out in the north western part off Simeuleu, it was found that a relatively wider range of fish 
Table 4. Catch rates of deep sea fish resources in each depth zone in the waters of Western Sumatera (Indian Ocean)

\begin{tabular}{|c|c|c|c|c|}
\hline \multirow{2}{*}{\multicolumn{5}{|c|}{$\begin{array}{c}\text { Items/Depth zone } \\
\text { South-Eastern part of Enggano }\end{array}$}} \\
\hline & 3 & 3 & 4 & 10 \\
\hline Catch rates (kgs per hr) & & & & 10 \\
\hline Minimum & 27.3 & 5.52 & 31.0 & 5.5 \\
\hline Maximum & 124.4 & 330.1 & 202.5 & 330.1 \\
\hline Mean & 81.0 & 121.7 & 103.2 & 102.1 \\
\hline Std. Dev. (s) & 49.3 & 180.9 & 72.0 & 99.1 \\
\hline Coef. Var. $(\%)$ & 60.9 & 148.6 & 69.8 & 97.0 \\
\hline Western part off Bengkulu & & & & \\
\hline No. of Station ( $n$ ) & - & 2 & 2 & 4 \\
\hline $\begin{array}{l}\text { Catch rates (kgs per } \mathrm{hr} \text { ) } \\
\text { Minimum }\end{array}$ & - & & & \\
\hline $\begin{array}{l}\text { Minimum } \\
\text { Maximum }\end{array}$ & - & $\begin{array}{l}7.5 \\
18.1\end{array}$ & $\begin{array}{l}17.5 \\
20.5\end{array}$ & $\begin{array}{c}7.5 \\
20.5\end{array}$ \\
\hline $\begin{array}{l}\text { Maximum } \\
\text { Mean }\end{array}$ & - & 12.8 & 19.0 & 15.91 \\
\hline Std. Dev. (s) & - & 7.5 & 2.2 & 5.7 \\
\hline Coef. Var. $(\%)$ & - & 58.4 & 11.4 & 36 \\
\hline North Western part of Simeuleu & & & & \\
\hline $\begin{array}{l}\text { No. of Station }(n) \\
\text { Catch rates (kgs per hr) }\end{array}$ & 1 & 12 & 12 & 25 \\
\hline Minimum & - & 8.8 & 3.3 & 3.3 \\
\hline Maximum & - & 90.1 & 81.5 & 90.1 \\
\hline Mean & 43.4 & 45.7 & 25.8 & 36.1 \\
\hline Std. Dev. (s) & - & 29.7 & 22.4 & 27.2 \\
\hline Coef. Var. (\%) & - & 65.1 & 86.9 & 75.0 \\
\hline $\begin{array}{l}\text { Western part off Banda Aceh } \\
\text { No. of Station }(n)\end{array}$ & & & & \\
\hline Minimum & 5.2 & 24.6 & 23.8 & 5.2 \\
\hline Maximum & 13.2 & 270.4 & 188.5 & 270.4 \\
\hline Mean & 8.4 & 110.0 & 84.8 & 73.1 \\
\hline Std. Dev. (s) & 4.2 & 114.4 & 75.2 & 86.5 \\
\hline Coef. Var. (\%) & 50.4 & 104.0 & 88.7 & 118 \\
\hline
\end{tabular}

densities in each depth zone have been observed. The minimum density in this waters was between 0.08 to 0.24 tonnes $\mathrm{km}^{-2}$ with the maximum between 2.4 to 2.7 tonnes $\mathrm{km}^{-2}$. The estimated total biomass in this area was about 4,827 tonnes. This was contributed from the previous three zones of $455 ; 2,525$; and 1847 tonnes respectively. Similar with the area off Simeuleu, in the western part off Banda Aceh, the northest fishing area during this cruise, a relatively wider range of fish density has also been detected. The minimum density within the three depth zones was 0.2 tonnes $\mathrm{km}^{-2}$, while the maximum density was 17,714 tonnes $\mathrm{km}^{-2}$. The average density beginning from the shallower to the deeper depth zones were $0.26,5.7$, and 2.5 tonnes $\mathrm{km}^{-2}$ respectively. The total biomass in this area was about 4,491 tonnes. This figure was cummulated from the three depth zone of 90 ; 2,905 ; and 1,497 tonnes respectively. Other information regarding the density and the standing stock size of the deep sea fish in the western part of Sumatera of the Indian Ocean is presented in Table 5 .

The Russian investigation in the western tropical Pacific Ocean and the seas on the Indo-Australian Archipelago produced a wealth of mesopelagic fishes. The biomass of these fishes in the entire water column to 1,000 metres had been measured. In the Kuroshio zone the density of fish were 5.0 to $6.0 \mathrm{mg} \mathrm{m}^{-3}$; equatorial waters, 3.1 to $8.1 \mathrm{mg} \mathrm{m}^{-3}$; central water mass 0.6 to $2.0 \mathrm{mg} \mathrm{m}^{-3}$. Their investigation barely extended to the bathypelagic fish fauna. In the waters column from 1,000 to $4,000 \mathrm{~m}$, the comparable biomass is likely to fall to a tenth of the mesopelagic value. Eventhough these results could not directly be compared with the present finding due to the differences in the method of measurements, the following estimation of demersal fish from the western of the North Atlantic waters has been reported by Heidrich \& Rowe in 1977 (Marshall, 1979). Based on 116 trawl 
Table 5.

Estimated mean stock density (tonnes $\mathrm{km}^{-2}$ ) and standing stock size (tonnes) in the waters of Western Sumatera

\begin{tabular}{|c|c|c|c|c|}
\hline Items/Depth zone & $<500 \mathrm{~m}$ & $500-750 \mathrm{~m}$ & $751-1,000 \mathrm{~m}$ & Total \\
\hline \multicolumn{5}{|l|}{ South-Eastern part of Enggano } \\
\hline No. of Station $(n)$ & 3 & 3 & 4 & \\
\hline Stock density & 2,271 & 3,807 & 3,126 & \\
\hline Trawlable area $\left(\mathrm{km}^{2}\right)$ & 308.24 & 309.76 & 414.96 & $1,032.96$ \\
\hline Standing Stock & 700.0 & $1,179.3$ & $1,297.2$ & $3,176.5$ \\
\hline \multicolumn{5}{|l|}{ Western part off Bengkulu } \\
\hline No. of Station $(n)$ & - & 2 & 2 & \\
\hline Stock density & $-\cdot$ & 0.408 & 0.559 & \\
\hline Trawlable area $\left(\mathrm{km}^{2}\right)$ & - & 18.37 & 98.31 & 116.68 \\
\hline Standing Stock (tonnes) & - & 7.5 & 55.0 & 62.5 \\
\hline \multicolumn{5}{|l|}{ North-Western part off Simeuleu } \\
\hline No. of Station $(n)$ & 1 & 12 & 12 & \\
\hline Stock density & 2,079 & 1,349 & 0.760 & \\
\hline Trawlable area $\left(\mathrm{km}^{2}\right)$ & 218.70 & $1,871.97$ & $2,429.85$ & $4,520.51$ \\
\hline Standing Stock (tonnes) & 454.7 & $2,525.3$ & $1,846.7$ & $4,826.7$ \\
\hline \multicolumn{5}{|l|}{ Western off Banda Aceh } \\
\hline $\begin{array}{l}\text { No. of Station (n) } \\
\text { Stock density }\end{array}$ & 3 & $\begin{array}{c}4 \\
5605\end{array}$ & 4 & \\
\hline Area $\left(\mathrm{km}^{2}\right)$ & $\begin{array}{c}0.263 \\
341.72\end{array}$ & $\begin{array}{c}5,695 \\
510\end{array}$ & $\begin{array}{c}2,484 \\
60246\end{array}$ & \\
\hline Standing Stock (tonnes) & 89.9 & $2,904.5$ & $\begin{array}{l}002.46 \\
1,496.5\end{array}$ & $\begin{array}{l}1,454.18 \\
4,490.9\end{array}$ \\
\hline
\end{tabular}

hauls, the fish which were identified and weighed, estimates of absolute abundance were obtained from a series of exposures in a pair of cameras. The density of fish, expressed in weight per square metre of bottom over areas between 497 to 2,780 $\mathrm{m}$, varied from 0.63 to $5.78 \mathrm{~g} \mathrm{~m}^{-2}$ (Marshall, 1979). This means that the estimated density of the deep sea fish in that area was between 6.3 to 57.8 tonnes $\mathrm{km}^{-2}$. Comparing with the density of deep sea fish in other part of the world ocean, particularly in the North Atlantic waters, it can be stated that the density of fish in the western part of Sumatera of the eastern Indian Ocean during the survey period was relatively low.

From experimental fishing using bottom long line in the waters of Semangka Bay, Lampung, three species of deepsea fish that never been seen before in any other part of the Sunda shelf were Gepyroberix sp., one species from the family of Triglidae and one species from family of Macrouridae (Hufiadi et al., 2003). The colour of the first two species was reddish and bright red. It was informed that Gepyroberix sp. has been normally consumed in Japan. The species of Peristedion sp. of the family of Triglidae provides a very poisonous fish (Figure 2 and 3 ). In general, it is likely that until recently the exploratory trawling of the deepsea demersal fish are still considered as one of the scientifics purposes rather than searching fish resources for direct human consumption. Some implications from the environmental aspects such as a very huge pressure and scarcity of food supply, it is likely that the deep sea fishes would have a very high sustainment for survive. The most interesting biological aspect is that the chemical substances of their flesh, such as protein, lipid and other biochemical substances which will need further pharmacological laboratory analysis and research. It was reported by the crews of the research vessel during this cruise that they were hardly ever to sleep for the whole night after they consumed the 'boiled' alepochepalid fish (Bajacalifornia erimorensis). This aspect seems to be important for the future frontier research in the framework of the exploitation of fish resources biodiversity.

\section{Catch Composition}

\section{Catch composition in the SE off Enggano}

The availability of catch composition data provide one of the basic information needed for the development of resources exploitation. In each depth stratum there were at least three species from three different families dominated the catch. In the depth stratum of $<500 \mathrm{~m}$, these species were Plesiobatis sp. (Plesiobatididae), Diaphus sp.1 (Myctophidae), and Ostracoberyx dorgenys (Ostracoberycidae). These three species amounted to about $60 \%$ of the total catch in the stratum, while the rests consisted of more than 10 species (Table $6)$. 


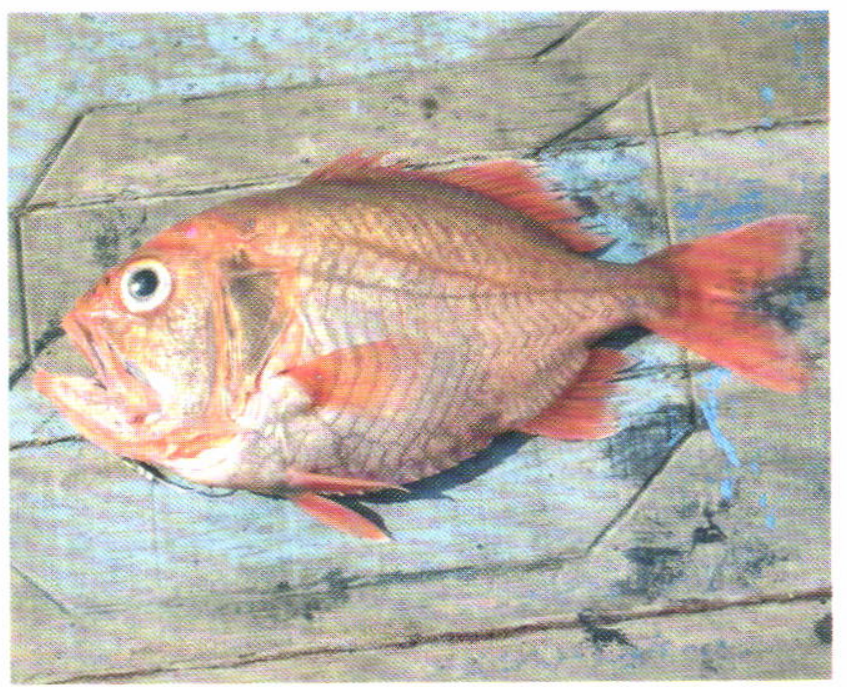

Figure 2. Gepyroberix sp. deep sea fish species caught by bottom long line in the wateis of Semangka Bay, Lampung.

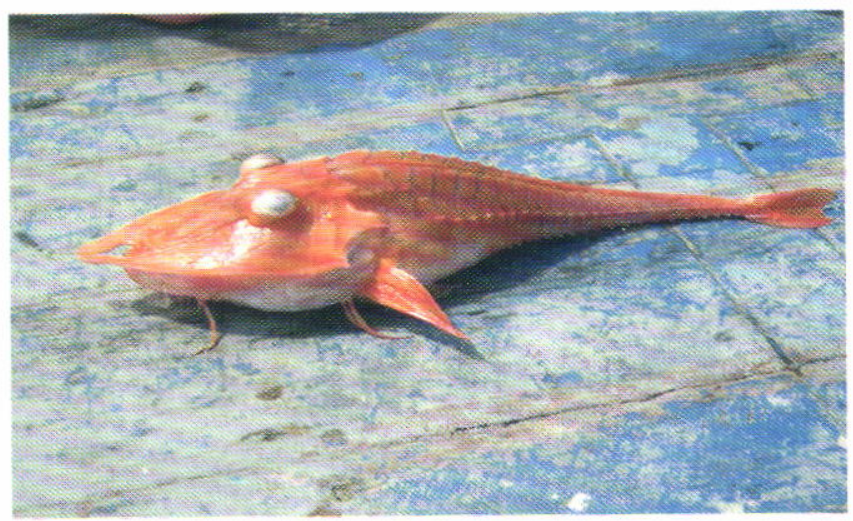

Figure 3. Peristedion sp. (Triglidae), a very poisonous deep sea fish caught by bottom long line in the waters of Semangka Bay, Lampung.

The Diaphus sp. 1 is one of the species of Myctophidae. The myctophid which is also known as the lantern fishes provides the most diverse mesopelagic fish in both number of species and individuals (Marshall, 1979). It was likely that an acoustically detected large schooling traces found in the Bay of Tomini at the depth of more than 200 $\mathrm{m}$ during the east monsoon in 2003 provide one the examples (Anonymous, 2005).

The three dominant species found in the 500 to $750 \mathrm{~m}$ depth stratum were Mitsukurina owstoni (Mitsukuiridae), Setarches guentheri (Scorpaenidae), and Plesiobatis sp. (Plesiobatididae), which amounted to about approximatelly $81 \%$ of the total catch. Within the stratum of 750 to $1,000 \mathrm{~m}$, there were also three dominant species, Mitsukurina owstoni (Mitsukuiridae), Hexatrygon longirostra (Hexatrygonidae), and Plesiobatis sp. (Plesiobatididae) that amounted to about $65 \%$ of the total catch in this stratum. It can be stated that the species of Plesiobatis sp., provides the most. wider depth range distribution as the fish species always occurred in each depth stratum. Other species that were likely to be found substantially in the depth strata were the family of Macrouridae and Alepocephalidae.

\section{Catch composition in the western part off Bengkulu}

In the western part off Bengkulu area the trawl samples covered only two depth strata, the 500 to $750 \mathrm{~m}$ and the 750 to $1,000 \mathrm{~m}$ as the trawlable ground was only found within the depth range of 500 to $1,000 \mathrm{~m}$.

The most dominated fish families found in the catch were Ophidiidae, Marouridae, and Chimaeridae. In the depth stratum of 500 to $750 \mathrm{~m}$, the Ophidiidae sp.1 and Lamprogrammus niger, 
Table 6.

Percentage catch composition of deepsea fish in the south eastern part of Enggano island

\begin{tabular}{|c|c|c|c|c|c|}
\hline Depth ranges (m) & $<500$ & $500-750$ & & $750-1,000$ & \\
\hline Plesiobatididae & & Mitsukurinidae & & Mitsukurinidae & \\
\hline $\begin{array}{l}\text { Plesiobatis sp. } \\
\text { Plesiobatis daviesi }\end{array}$ & $\begin{array}{c}27.2 \\
4.3\end{array}$ & $\begin{array}{l}\text { Mitsukurina owstoni } \\
\text { Scorpaenidae }\end{array}$ & 41.1 & $\begin{array}{l}\text { Mitsukurina owstoni } \\
\text { Hexatrygonidae }\end{array}$ & 36.3 \\
\hline Myctophidae & & Setarches guentheri & 26.9 & Hexatrygon longirostra & 15.9 \\
\hline Diaphus sp.1 & 16.6 & Plesiobatididae & & Plesiobatididae & \\
\hline Ostracoberycidae & & Plesiobatis sp. & 12.8 & Plesiobatis sp. & 12.5 \\
\hline Ostracoberyx dorgenys & 16.0 & Neoscopelidae & & Plesiobatis daviesi & 4.5 \\
\hline Grammicolepididae & & Neoscopelus macrolepidotus & 4.8 & Macouridae & \\
\hline Xenolepidichthys dalgleishi & 5.8 & Torpedinidae & & Caelorinchus divergens & 6.3 \\
\hline $\begin{array}{l}\text { Squatinidae } \\
\text { Squatina tergocellatoides }\end{array}$ & 3.5 & $\begin{array}{l}\text { Torpedo tokionis } \\
\text { Moridae }\end{array}$ & 3.2 & $\begin{array}{l}\text { Caelorinchus sp. } 1 \\
\text { Centrophoridae }\end{array}$ & 1.8 \\
\hline Macrouridae & & Halargyreus sp. & 1.4 & Centrophorus sp.2 & 3.6 \\
\hline Ventrifossa sp.1 & 3.2 & Alepocephalidae & & Melanonidae & \\
\hline Ventrifossa sp.2 & 2.1 & Alepocephalus bicolor & 1.4 & Melanonus zugmayeri & 2.7 \\
\hline Trichiuridae & & Xenodermichthys nodulosus & 0.9 & Alepocephalidae & \\
\hline Benthodesmus tenuis & 2.6 & Trichiuridae & & Bajacalifornia erimoensis & 2.1 \\
\hline Xiphiidae & & Benthodesmus elongatus & 0.1 & Alepocephalus bicolor & 1.1 \\
\hline $\begin{array}{l}\text { Xiphus gladius } \\
\text { Zeidae }\end{array}$ & 2.4 & Miscellaneous & 7.4 & $\begin{array}{l}\text { Talismania sp. } \\
\text { Ophidiidae }\end{array}$ & 0.7 \\
\hline Zenopsis conchifer & 2.2 & & & Lamprogrammus niger & 2.0 \\
\hline Acropomatidae & & & & Macrouroidae & \\
\hline Synagrops japonicus & 2.1 & & & Squalogadus modificatus & 1.6 \\
\hline Miscellaneous & 12.0 & & & Miscellaneous & 8.5 \\
\hline Total (\%) & 100.0 & & 100.0 & & 100.0 \\
\hline Total catch (kgs) & 242.9 & & 365.0 & & 412.8 \\
\hline
\end{tabular}

Table 7. Percentage catch composition of deep sea fish in the westhern part off Bengkulu

\begin{tabular}{|c|c|c|c|}
\hline Depth ranges (m) & $500-750$ & $750-1,000$ & \\
\hline Ophidiidae & & Macrouridae & \\
\hline Ophidiidae sp.1 & 24.3 & Caelorinchus divergens & 33.9 \\
\hline Lamprogrammus niger & 2.6 & Nezumia sp.1 & 1.2 \\
\hline Macrouridae & & Ventrifossa sp. 1 & 1.0 \\
\hline Caelorinchus divergens & 21.4 & Chimaeridae & \\
\hline $\begin{array}{l}\text { Gadamus colletti } \\
\text { Barbourisiidae }\end{array}$ & 3.1 & $\begin{array}{l}\text { Chimaera sp. } \\
\text { Congridae }\end{array}$ & 23.4 \\
\hline Barbourisia rufa & 6.9 & Congridae sp.1 & 5.4 \\
\hline Alepocephalidae & & Muraenesocidae & \\
\hline Bajacalifornia erimoensis & 6.8 & Muraenesocidae sp. & 4.8 \\
\hline Alepocephalus sp. 1 & 2.9 & Alepocephalidae & \\
\hline Narcetes sp. & 1.4 & Bajacalifornia erimoensis & 4.1 \\
\hline Talismania sp. & 1.6 & Rouleina guentheri & 2.7 \\
\hline Neoscopelidae & & Alepocephalidae sp.1 & 2.9 \\
\hline Neoscopelus macrolepidotus & 5.5 & Melanonidae & \\
\hline Scopelengys tristis & 3.0 & Melanonus zugmayeri & 2.9 \\
\hline Synaphobranchidae & & Asteronesthidae & \\
\hline $\begin{array}{l}\text { Synaphobranchus sp. } \\
\text { Melanonidae }\end{array}$ & 2.8 & $\begin{array}{l}\text { Heterophotus ophistoma } \\
\text { Neoscopelidae }\end{array}$ & 2.4 \\
\hline $\begin{array}{l}\text { Melanonus zugmayeri } \\
\text { Halosauridae }\end{array}$ & 2.7 & $\begin{array}{l}\text { Neoscopelus macrolepidotus } \\
\text { Diceratiidae }\end{array}$ & 1.8 \\
\hline Aldrovandia affinis & 2.4 & Diceratiidae sp. & 1.3 \\
\hline Miscellaneous & 12.6 & Miscellaneous & 12.2 \\
\hline Total $(\%)$ & 100.0 & & 100.0 \\
\hline Total catch (kgs) & 25.6 & & 38.03 \\
\hline
\end{tabular}


Table 8.

Percentage catch composition of deep sea fish in the north western part of Simeuleu island

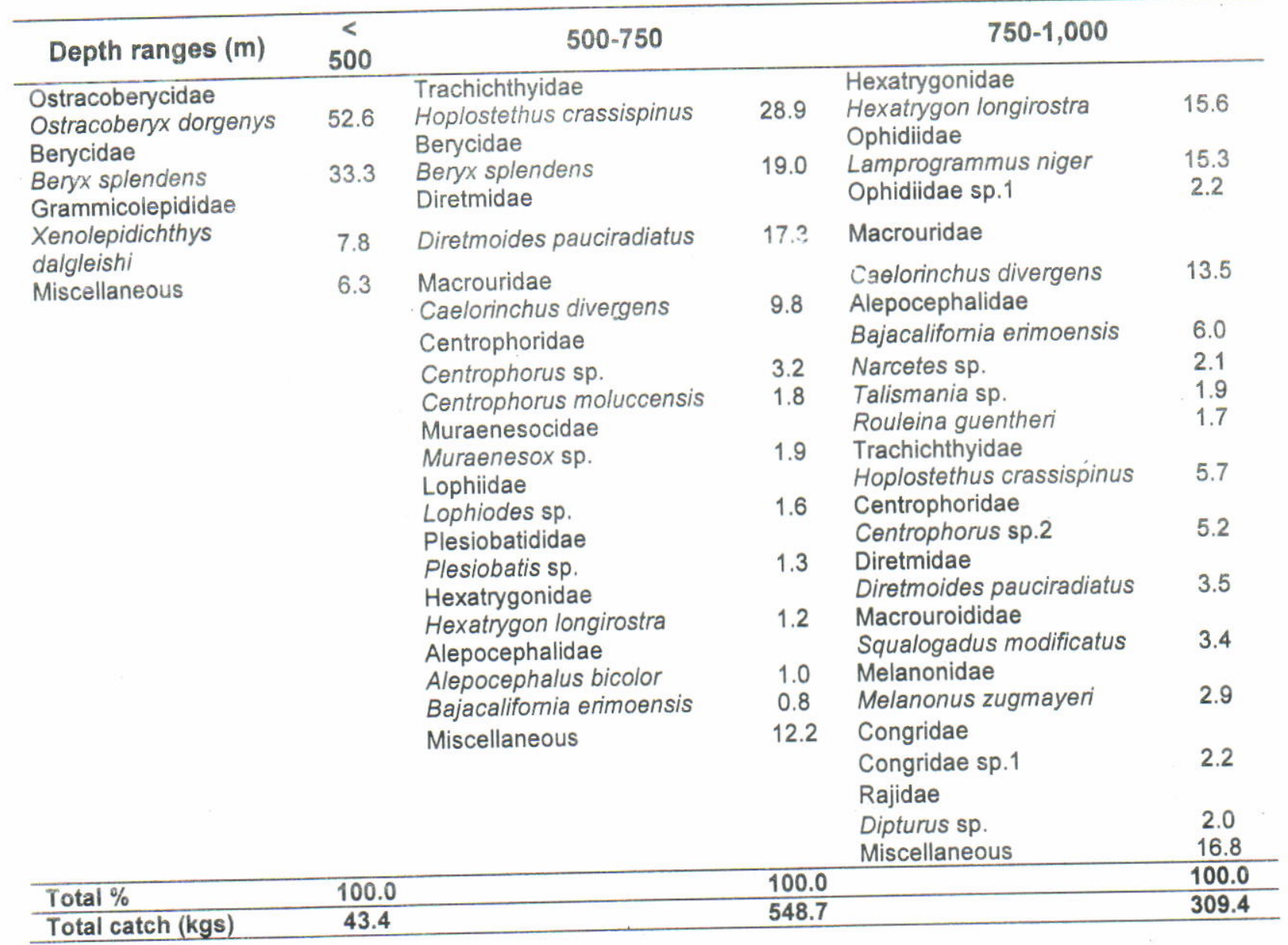

both of them made up to $27 \%$, followed by Caelorinchus divergens of the family of Macrouridae. The last species of Macrouridae has also dominated the catch within the stratum of 750 to $1,000 \mathrm{~m}$ that reached to about $34 \%$, while the second dominated species was the rat tails Chimaera sp. (Chimaeridae) amounted to about $23 \%$ (Table 7 ). The rest of the catch consisted of more than 15 species in each stratum.

\section{Catch composition in the NW Simeuleu}

More than $93 \%$ of the total catch in stratum $<500 \mathrm{~m}$ contibuted by only three species. These were Ostracoberyx dorgenys (Ostracoberycidae), Beryx splendens (Berycidae), and Xenolepidichthys dalgleishi (Grammicolepididae) with the percentage of about 53,33 , and $8 \%$ respectively. The most dominant species found within the depth stratum of 500 to $750 \mathrm{~m}$ were Hoplostethus crassispinus (Trachichthyidae), Beryx splendens (Berycidae), Diretmoides pauciradiatus (Diretmidae), and Caelorinchus divergens (Macrouridae) with the respective percentage of about $29,19,17$, and $10 \%$. With the relatively lower percentage catch composition, the species of Hexatrygon longirostra (Hexatrygonidae), Lamprogrammus niger (Ophidiidae), and Caelorinchus divergens (Macrouridae) were substantially found in the catch (Table 8). The species of Beryx splendens was likely to have wide depth distribution as this species was found in both depth range of $<500 \mathrm{~m}$ and 500 to $750 \mathrm{~m}$. The similar case were also applied to the species of Hoplostethus crassispinus (Trachichthyidae), Caelorinchus divergens (Macrouridae), Diretmoides pauciradiatus (Diretmidae), Centrophorus sp. (Centrophoridae) and Bajacalifornia erimoensis (Alepocephalidae) that occurred in the deeper water of both the strata 500 to $750 \mathrm{~m}$ and 750 to $1,000 \mathrm{~m}$. The species of Hexatrygon longirostra, the second dominant species within the stratum of 750 to $1,000 \mathrm{~m}$ in the waters around Enggano Island, provided the most dominated the catch within the same stratum in the waters around Simeuleu island. 
Percentage catch composition of deep sea fish in the westhern part off Banda Aceh

\begin{tabular}{|c|c|c|c|c|c|}
\hline Depth ranges $(\mathrm{m})$ & $<500$ & $500-750$ & & $750-1,000$ & \\
\hline Myctophidae & & Diretmidae & & Alopiidae & \\
\hline Diaphus sp.1 & 22.2 & Diretmoides pauciradiatus & 36.2 & Alopias superciliosus & 26.7 \\
\hline Plesiobatididae & & Ostracoberycidae & & Diretmidae & \\
\hline Plesiobatis sp. & 22.1 & Ostracoberyx dorgenys & 33.9 & Diretmoides pauciradiatus & 25.4 \\
\hline $\begin{array}{l}\text { Zeidae } \\
\text { Zenopsis conchifer } \\
\text { Polymixiidae }\end{array}$ & 18.6 & $\begin{array}{l}\text { Trachichthyidae } \\
\text { Hoplostethus rubellopterus } \\
\text { Macrouridae }\end{array}$ & 5.7 & $\begin{array}{l}\text { Trachichthyidae } \\
\text { Hoplostethus rubellopterus } \\
\text { Macrouridae }\end{array}$ & 14.1 \\
\hline $\begin{array}{l}\text { Polymixia japonicus } \\
\text { Ostracoberycidae }\end{array}$ & 8.0 & $\begin{array}{l}\text { Caelorinchus divergens } \\
\text { Nettastomatidae }\end{array}$ & 3.8 & $\begin{array}{l}\text { Caelorinchus divergens } \\
\text { Centrophoridae }\end{array}$ & 7.9 \\
\hline Ostracoberyx dorgenys & 6.2 & Nettastoma solitarium & 3.8 & Centrophorus sp. 2 & 6.4 \\
\hline Chlorophthalmidae & & Plesiobatididae & & Centrophorus moluccensis & 5.7 \\
\hline Chlorophthalmus sp.1 & 4.6 & Plesiobatis sp. & 3.4 & Nettastomatidae & \\
\hline $\begin{array}{l}\text { Caproidae } \\
\text { Antigonia capros } \\
\text { Berycidae }\end{array}$ & 2.6 & $\begin{array}{l}\text { Centrophoridae } \\
\text { Centrophorus moluccensis } \\
\text { Paralepididae }\end{array}$ & 3.1 & $\begin{array}{l}\text { Nettastoma solitarium } \\
\text { Miscellaneous }\end{array}$ & $\begin{array}{l}4.3 \\
9.5\end{array}$ \\
\hline $\begin{array}{l}\text { Beryx splendens } \\
\text { Miscellaneous }\end{array}$ & $\begin{array}{c}2.4 \\
13.3\end{array}$ & $\begin{array}{l}\text { Notoleptis rissoi } \\
\text { Miscellaneous }\end{array}$ & $\begin{array}{l}2.6 \\
7.5\end{array}$ & & \\
\hline Total $(\%)$ & 100.0 & & 100.0 & & 100.0 \\
\hline Total catch (kgs) & 25.3 & & 439.9 & & 339.0 \\
\hline
\end{tabular}

Catch composition in the western part off Banda Aceh

The catch composition in the western part off Banda Aceh seems to be the lesser diverse in catch composition compared with the previous areas of Western part of Sumatera. Similar with the composition in the previous areas where the catches in the depth stratum $<500 \mathrm{~m}$ were dominated by the species of Plesiobatis $\mathrm{sp}$. (Plesiobatididae) and Diaphus sp.1 (Myctophidae), in the North western part of Simeuleu Island the species of Diaphus sp.1 and Plesiobatis sp. provide the most dominant species found in the catches with the respective percentage of each species of about $22 \%$.

The third dominant species in this stratum was Zenopsis conchifer (Zeidae) of about 19\%, followed by Polymixia japonicus (Polymixiidae) which percentage to about $8 \%$. The other species in this stratum consisted of about more than 6 species, where each species contributed to only $<6 \%$ (Table 9).

In the depth stratum 500 to $750 \mathrm{~m}$, more than two-third of the catches were contributed by the species of Diretmoides pauclradiatus and Ostracoberyx dorgenys that reached to about $70 \%$ of the total catch in the stratum. The rests of the catches consisted of more than 7 species, each of the species contributed to only $<5 \%$. The first species of Diretmidae that was dominated in this stratum, has been the second dominant species in the depth stratum of 750 to $\$, 000 \mathrm{~m}$, that contributed to about $25 \%$ of the total catch in this stratum. The first dominated species was contributed by deep sea shark, Alopias superciliosus of the family Alopiidae. The third dominant species amounted to about $14 \%$ of the total catch in this stratum was Hoplostethus rubellopterus.

\section{CONCLUSION}

From the analysis of only fish resources it was found that the highest mean catch rate of about $121.7 \mathrm{kgs}$ per hr was occurred in the depth range of 500 to $750 \mathrm{~m}$, in the south western part of Enggano area, while the lowest mean catch rate of $3,3 \mathrm{kgs}$ per hr was occurred in the depth zone 751 to 1,000 $\mathrm{m}$ in the waters of North Western Simeuleu. The lowest density of about 0.08 tonnes $\mathrm{km}^{-2}$ was observed in the depth zone of 751 to $1,000 \mathrm{~m}$ in the north western part of Simeuleu, while the highest density of 17,714 (17.7) tonnes $\mathrm{km}^{-2}$ was occurred in the depth zone 500 to $750 \mathrm{~m}$ in the western part off Banda Aceh. By multiplying the estimated sea surface areas and the mean density in each depth zone and in the survey area, the total deep-sea fish standing stock size can be calculated.

As reflected by the Richness index of Margaleff, within the depth range of 250 ' to $1000 \mathrm{~m}$ in the waters of Western Sumatera, the number of species seems to increase toward the deeper waters. The six species of important in term of numbers of individual fish available were the lantern fish myctophids, Diaphus sp.1, the rat tails macrourid, Caelorinchus divergens, the neoscopelids, Neoscopelus macrolepidotus, the 
spinyfins, Diretmoides pauciradiatus, the alepocephalid, Bajacalifornia erimorensis, and the trachichthyds Haplostetus crassispinus.

In relation with the environmental aspects such as the very huge pressure and scarcity of food supply, it is likely that the deep sea fishes would have a very high sustainment for survive. In this aspect, the chemical substances of their flesh, such as proteins, lipids, and other biochemical substances will need further pharmacological laboratory analysis and research.. These aspects seem to be important for the future frontier research. It is advised that exploitation of deep sea fish resources nowadays shoud be directed to get the benefit from the fish resources biodiversity and bio active substance rather than searching fish for direct human consumption.

\section{REFERENCES}

Anonymous. 2005. Gulf of Tomini: Ecology, fish resources potential, fisheries profile, and biology of some economically important fish. Res. Inst. for Mar. Fish. RCCF. 114 p. (In Indonesian).

Anonymous. 2006. The Japan-Indonesia deep sea fishery resources joint exploration project. November. 2005. Project Report. OFCF-RIMF. $151 \mathrm{p}$.

Anonymous. 1992. Background fisheries statistics. DPIE. Canberra. Australia. August 1992. Issu Number $6.47 \mathrm{p}$.

Badrudin, N. N. Wiadnyana, \& B. Wibowo. 2005. Deep water exploratory bottom long lining in the waters of the Arafura Sea. Indonesian Fisheries Research Journal. AMFR. MMAF. Vol.11. No.1 (2005): 41-46.

Badrudin, B. Sumiono, \& S. Nurhakim. 2004. Hook rates and compositions of bottom long line catches in the waters of the Arafura Sea. Indonesian Fisheries Research Journal. AMFR. MMAF. Vol.10. No.1. (2004): 9-14.

Badrudin, S. Nurhakim, \& B. Fegan. 2004a. Catch rate and catch composition of trawl fish net in the Arafura Sea. Indonesian Fisheries Research Journal. AMFR. MMAF. Vol.10. No.1. (2004): 1-7.

Badrudin, B. Sumiono, \& N. Wirdaningsih. 2002. Catch rate, maximum sustainable yield, and optimum effort of shrimp fisheries in the Arafurs Sea. Indonesian Fisheries Research Journal.
Vol.8 (4): 23-30. (In Indonesian with English abstract)

Badrudin \& B. Sumiono. 2002. Stock abundance index and shrimp proportion In the demersal fish community in the Aru islands, Arafura Sea. Indonesian Fisheries Research Journal. Vol.8 (1): 95-102. (In Indonesian with English abstract).

Dahuri, R. 2003. Marine biodiversity. An Indonesian sustainable cievelopment asset. PT. Gramedia Pustaka Utama. Jakarta. 412 p. (In Indonesian).

Dwiponggo, A. \& M. Badrudin. 1978. Demersal resources survey in the coastal area of the Java Sea in 1977. Special Report. Contrib. of the Dem. Fish. Project. No.5. RIMF-GTZ. Jakarta. $14 \mathrm{p}$.

Dwiponggo, A. \& M. Badrudin. 1979. Variation in catch rates and species composition of trawl survey in the Java Sea sub areas. Special Report. Contrib. of the Dem. Fish. Project. No.6. RIMF-GTZ. Jakarta. $19 \mathrm{p}$.

Dwiponggo, A. \& M. Badrudin. 1980. Resutls of the Java Sea inshore monitoring survey. Special Report. Contrib. of the Dem. Fish. Project. No.7. RIMF. Jakarta. $31 \mathrm{p}$.

Gulland, J. A. 1983. Fish stock assessment. A manual of basic methods. Vol.1. FAO Wiley series on Food and Agriculture. John Wiley \& Sons. $223 \mathrm{p}$.

Hufiadi, Awwaludin, \& T. S. Murtoyo. 2003. Fishery resources survey in the southern waters of Lampung. Internal Technical Report. RIMF. Jakarta. 11 p. (In Indonesian).

Losse, G. F. \& A. Dwiponggo. 1977. Report on the Java Sea southeast monsoon trawl survey June to December 1976. Special Report. Contrib. of the Dem. Fish. Project. No.3. 1977. RIMF. Jakarta. $119 \mathrm{p}$.

Ludwig, J. A. \& J. F. Reynolds. 1988. Statistical ecology. A Primer on Methods and Computing. John Wiley \& Sons. New York. $337 \mathrm{p}$.

Marshall, N. B. 1979. Development of deep sea biology. Blanford Press Poole. Dorset. U. K. 565 p.

Nakabo, T. 2002. Fishes of Japan with pectorial keys to the species. Tokai University Press. Book I: 866 p. Book II: 867-1748. 
Deep Sea Fish Resources ..... in the Waters of Westem Sumatera of the Easterm Indian Ocean (Badrudin, et al.)

Nybakken, J. W. 1986. Marine biology: An ecological approach (In Indonesian. Transiators: M. Eidman, Koesoebiono, Dietrich, Hutomo, \& Sukardjo). PT. Gramedia. Jakarta.

Saeger, J., P. Martosubroto, \& D. Pauly. 1976. First report of the Indonesian-German demersal fisheries project (Results of a trawl survey in the Sunda Shelf areas). Special Report. Contrib. of the Dem. Fish. Project. No.1. 1976. RIMF. Jakarta. $46 \mathrm{p}$.
Shindo, S. 1973. General review of the trawl fishery and the demersal fish stock of the South China Sea. FAO Fish. Tech. Pap. (120): 49 p.

Wibowo, B. 2005. Deep sea fish resources research in the Indian Ocean. Technical Internal Report. Research Center for Capture Fisheries in co operation with PT. Bahtera Adimina Samudera TBK. Research Center for Capture Fisheries. Jakarta. 16 p. (In Indonesian) 
